\title{
Readiness Model in Adopting E-health: An Indonesian Experience
}

\author{
Vera Pujani ${ }^{1}$, Hardisman Dasman ${ }^{2}$, Rima Semiaty ${ }^{2}$, Refdinal Nazir ${ }^{3}$ \\ ${ }^{1}$ Department of Management, Andalas University, Padang, Indonesia \\ ${ }^{2}$ Faculty of Medical, Andalas University, Padang, Indonesia \\ ${ }^{3}$ Department of Electrical Engineering, Andalas University, Padang, Indonesia
}

\begin{abstract}
This study aims to investigate e-health use in some hospitals in Indonesia through the readiness model. The readiness factor identified as the core, societal, technological and engagement readiness also expected efforts. The research model measured the influence of the readiness factors on e-health adoption and their impact on performance. A-104 respondent of e-health user among hospitals across Indonesia were obtained accidentally in the e-survey technique. The data was analysed to test six hypotheses using SEM/PLS. The result of this study identified four out of six hypotheses tested significantly influenced including core, societal, and technological readiness and impacted on performance achievement.
\end{abstract}

Keywords - E-health, Hospital Information Systems, e-readiness, adoption model, Indonesia.

\section{Introduction}

Information systems in health sectors and hospitals are useful to facilitate the community gaining the access of information around the health information. The service delivery of the health system electronically (e-health) is the use of the application system in conducting various activities in healthcare including the Personally Controlled Electronic Health Record (PCEHR), telemedicine, telehealth or

DOI: 10.18421/TEM101-12

https://doi.org/10.18421/TEM101-12

Corresponding author: Vera Pujani,

Department of Management, Andalas University,

Padang Indonesia.

Email: verapujani@eb.unand.ac.id

Received: 08 September 2020.

Revised: 09 January 2021.

Accepted: 14 January 2021.

Published: 27 February 2021.

(c) Br-NC-ND (c) 2021 Vera Pujani et al; published by UIKTEN. This work is licensed under the Creative Commons Attribution-NonCommercial-NoDerivs 4.0 License.

The article is published with Open Access at www.temjournal.com websites-based [1], [2], [3]. The implementation of information systems in health industries has been believed as the main asset of numerous hospitals especially in delivering services to the public society [4]. However, the use of information systems in the health industry is not easy, and nearly $70 \%$ is having a failure rate including tract record which remains poor and high cost initiative [5].

The utilization of health information systems would be able to transform a new paradigm of the conventional healthcare system. It can be through standardization, medical systems and their impact on the healthcare quality, reducing healthcare costs, and empowering consumers, and then it has to be able to make informed decisions based on their needs [6]. There are numerous initiatives related to the health management systems including practice scheduling, prescribing and billing, information sourcing and sharing, service delivery (e.g. chronic disease support and tele-health), remote care management and wellness, clinical decision support (e.g. aid in collaborative diagnosis, treatment and care processes), e-health record (EHR) and public health intelligence [3]. The information system is better running under internet. The internet is a network that has widest range to everyone by providing information, so that it expands business opportunities throughout world [7]. Even with various benefits, ehealth is not always successful in its implementation because, there are several obstacles, for instance, system infrastructure - internet, hardware, software, and IT professionals provided [8], system operations, difficulties in consolidating, triangulating and analyzing the data [9].

Despite numerous benefits of e-health implementations which were well absorbed by developed countries, for instance Australia, United State, UK and European countries, in terms of effectiveness and efficiency processing [4], e-health implementations in developing countries was underdeveloped [10]. Utilization of information technology in developing countries is not as intensive as in developed countries, due to the limitation of organizational resource and ICT infrastructures [11]. As the result, there is still limited studies related to the e-health implementation in developing countries especially Indonesia [6]. 
In case of Indonesia context, the Indonesian Health Ministry has established the official regulation toward the use of information technology in the health sector, Hospital Management Information Systems and Regional Health Information systems, through inter-agency cooperation hospitals, governments, universities, private companies, and providers of telecommunications services [12]. Furthermore, Indonesia with more than 265 million populations with GDP 4130 US Dollars had have in total number 2.776 hospitals, which are in detail 2.198 as general hospitals and 578 as special hospitals and is added 9.825 Community Health Centers [13]. However, there is a long way to go for Indonesia as a developing country to have the same level of e-health application with those developed countries, even though there are the opportunities of e-health services that could be derived in future [14].

According to the Internet World Stat (2020) internet usage in Indonesia has the position as the four-biggest internet users in the world after China, India and United States, with the growth $8.56 \%$ during 2000-2020. In addition, the development of internet users in Indonesia reached $64.1 \%$ of total population of Indonesia. Therefore, IT-based health development is an important matter, and it is needed in Indonesia [15].

Using internet technology, information system in the health context would be expected to improve the service excellent and organizational performance, both external internal users' perspectives in its organizations [16]. Such the adoption model of Ehealth in Indonesia still underdeveloped, that the use of internet technology for effective and efficient improvement in health organizations is still relatively slow [17].

The failure in using e-health, not only related to technological aspect but also the lack of readiness is identified by time losses and money, also efforts, therefore, measurement of e-health readiness is a considered important [5]. The various studies measured the readiness factor in adopting e-health in Indonesia contexts in order to reach benefits in health sector were presented. The readiness in adoption related to core, structural, societal, engagement, effort and its performances aims to contextualize the framework application of e-health and readiness models [18], [19], [20].

As the reasons, the objective of research is to test readiness factors to give contribution on performance achievement in adopting e-health in Indonesian hospitals. The paper is organized by presenting sections including literature, methodology, results, conclusion and discussion.

\section{Literature Review}

Adoption model is identified as alternative factors of the success model in using the information technology in particularly the tendency to behave user acceptance during work with its technologies [21]. The seminal study of Davis's model is a belief of being able to measure the user acceptance related to usefulness and ease to use information technologies especially for collar workers [22]. In the meantime, there are prior measurements with reference to identifying toward implementation information technologies from Rogers [23], Delone and McLean [24] based on consequences in implementing information system, Seddon [24] the extension of DeLone and McLean's model (DM), Venkatesh, et. al. [25], which is unified model of acceptance model. However, these studies tend to investigate the individual rather than the organization perspective. Therefore, the study adoption model based on hospital perspectives to identify the impact of information system use related to hospital and country characteristics was presented [18], [26].

E-Readiness is identified as the electronically preparedness of practitioner, organization and public in adopting e-health systems [27]. The pioneering study of e-readiness model [28] measures Perceived Organizational e-Readiness and Perceived External e-Readiness in adopting e-commerce in developing countries. The model was adopted and extended to measure e-health readiness in developing countries contexts with numerous shortages for instance; lack of health facilities, health human resources [5], [10], failing to provide an IT infrastructure and knowledge base, risk falling both economically and socially [29]. Therefore, the study toward e-health adoption using readiness model in developing countries is measured for six hypotheses in following paragraph.

Core readiness was measured in the research model regarding a construct needed or motivational readiness of service provided using e-health, in order to gain personal and organizational benefits [30]. Again, the core attribute of e-health leads to change needed in organizational contexts [6], [10], [31]. To measure core readiness, there are numerous indicators including identification of needs, dissatisfaction, awareness, conform with technology, trust, planning, integration and overall satisfaction [10], [31]. As the result, the first hypothesis was developed as:

Hypothesis 1: Core readiness influences on ehealth adoption. 
Technological readiness refers to availability and affordability of hardware, software, internet/networks, ICT personnel and IT security [32], skilled human resources, ICT support, quality ICT infrastructure and power supply [5]. Accordingly, the second hypothesis in following paragraph was developed.

Hypothesis 2: Technological readiness influences on e-health adoption.

Societal readiness refers to the degree of interaction with healthcare institutions [5], and the staff participations of health institution on networked world especially in communicating and collaborating [6]. There were various indicators including health institution's collaborations, sharing information, socio-culture factor among staff. The third hypothesis was developed and based on societal readiness.

Hypothesis 3: Societal readiness influences on ehealth adoption.

Engagement Readiness refers to degree of the community exposed, willingness to change, accept training regarding e-health as well actively discussion its benefits obtained [5], additionally, potential impact, resistance to change, learnability, risk-takers [30, willingness to participate in the networking world [26]. As the result, the fourth hypothesis was developed.

Hypothesis 4: Engagement readiness influences on e-heath adoption.

Expected Effort refers to the level of ease with the use of technology recognized as a critical predictor of user behavior intentions and the experience in using technology especially e-health adoption [26]. Accordingly, the fifth hypothesis was developed.

Hypothesis 5: Expected effort influences on e-health adoption.

Performance refers to expectations, namely the extent to which the use of technology will provide benefits to consumers and lead to improved performance [33], performance expectancy and administration to facilitate using e-health systems [26]. The sixth hypothesis was developed and based on adoption and performances achievement.

Hypothesis 6: e-health adoption influences in achieving performance.

Briefly, there are six hypotheses developed to investigate readiness factors in adopting e-health in Indonesia contexts.

\section{Research Methodology}

The research sample was numerous hospitals in Indonesia as a developing country. The hospital has operated any related information systems including Indonesian National Health Insurance, Hospital Management Information Systems, Medical Record Systems, Pharmacy system and others health information systems. The ability of respondent in answering the questionnaire related to the implementation e-health information systems in their hospitals was the main consideration; it was also unlimited to its managers and owners. The accidental sampling technique was conducted by survey method on hospital managers and owners across Indonesia.

The data collection has been held on National Congress of Indonesian Hospital Association 2018 in Jakarta. One month before collecting the data, the permission of congress committees was received from the head of Congress Committee. There were more than 300 self-administrated questionnaires distributed to congress participants accidentally before they attended the congress, and finally 104 questionnaires returned and proper to be analyzed in next steps. The congress participant was the representative of hospitals across the country with different characteristics and categories for instance national and regional; general and special; private and public hospitals.

\subsection{Research Instrument}

The instrument of this research was designed and based on previous studies to evaluate readiness model and their impact on e-health adoption in Indonesian hospitals [19]. There are 47 items of questionnaires to investigate e-health adoption and readiness factors from hospital perspectives besides the data of the hospital profile. The questionnaires consist of 11-item of adoption indicators [34], and employed a 5-Likert scale. In the meantime, the readiness factors [26], [31] consist of 8-item for Core Readiness, 9-item for Structural readiness, 6-item for Societal readiness, 5-item Engagement readiness, 4item for Expected effort and 4-item for Performance indicators [24], [33] which employed a 5-scala which range is from very important [14] to completely not important [13].

The adoption of e-health system in hospitals refers to using technology system for business activities (ebusiness). Accordingly, e-health adoption was derived from business-oriented use related to interbusiness communication, coordinations and collaboration [34]. Again, adoption also refers to the nature of system use [24] based on functional and expected purposes. In the meantime, the readiness construct in using e-health system was derived from [6], [31] which are measured through the relative 
status of health institutions and systems' users in adopting ICT and information systems. Finally, performance refers to organizational benefits and strategic performances [24], [33].

\subsection{Data Analysis}

The data obtained was analyzed using structural equation modelling (SEM) with employed SmartPLS 3.00 version. PLS technique is identified as a component-based SEM and is suitable over variancebased SEM in predicting latent constructs without requiring normal distributions, interval scale and large sample size [4], [35]. There are two PLS procedures both tested in the measurement and structural model. Hence, the model measurement (outer model) identified validity and reliability testing including loading/weight scores, individual and composite reliability, and discriminant validity as well. To test hypotheses, structural measurement (inner model) to examine associations of readiness constructs related to adoption and their impact on performances were presented.

\section{Results}

\subsection{Respondent Profile}

In the first result of data analyses was the illustration of a 104-research respondent based on the profile of personal and hospital contexts (Table 1.). The personal profile presented 71.4 percent was female respondent and the rest was male respondents who was the majority age between 35-50-year-old. In addition, the majority of respondent had graduated at bachelor degrees (43.8\%) and magister degrees $(41.9 \%)$, which of whom 78 percent have health education background (medical doctor and nurses) and job position 68 percent as division managers. In the meantime, hospital profile presented that the location of more than 20 provinces, in which the majority was located in Jakarta and West Java. Again, hospital respondents have range of 100-300 beds provided in those hospitals with budget provided more than $70 \%$ respondents have IT budget less than $10 \%$ from total budget allocations.

\subsection{Measurement Analysis}

The measurement model (outer model) was to identify the reliability and validity tests. This research employed the minimum cut-off level of 0.6 for item loading as the reliability criteria [36]. The Appendix revealed that all constructs of model measured fulfilled those criterions of $\mathrm{CR}$ and AVE after removing EgR4 since the score is less than 0.6. Additionally, to measure reliability as the internal consistency, the composite reliability (CR), Cronbach Alpha (CA) and average variance extracted (AVE) were confirmed to meet the acceptable criterion with $\mathrm{CR} / \mathrm{CA}$ more than 0.7 and AVE more than 0.5[16]. Based on the results (Table 2), the value of AVE, CR and CA for each construct were acceptable criterion since over 0.5 for AVE and over 0.7 for CR and CA.

Table 1. Respondent Profile

\begin{tabular}{|c|c|c|c|c|c|}
\hline \multicolumn{2}{|c|}{ Measurement Items } & Percentage (\%) & \multicolumn{2}{|c|}{ Measurement Items } & \multirow{2}{*}{ Percentage (\%) } \\
\hline Gender & Male & 28.6 & Position & & \\
\hline \multirow{8}{*}{$\begin{array}{l}\text { Education } \\
\text { Level }\end{array}$} & Female & 71.4 & & Director & 21.1 \\
\hline & Total & 100 & & Head of Division & 65.4 \\
\hline & High School & 1.9 & & IT Expert & \\
\hline & Diploma & 96 & & Admin/Onerator & $\begin{array}{c}2.9 \\
10.6\end{array}$ \\
\hline & Bachelor & 43.8 & & Total & 100 \\
\hline & Master & 41.9 & & & \\
\hline & Ph.D. & 2.9 & No. Beds & $<50$ & 2.3 \\
\hline & Total & 100 & & $51-99$ & 24.1 \\
\hline \multirow[t]{11}{*}{ Expertise } & & & & $100-299$ & 31.0 \\
\hline & Medical & 39.0 & & $300-399$ & 29.9 \\
\hline & Nurse & 39.0 & & 400 and more & 12.7 \\
\hline & Computer & 2.9 & & Total & 100 \\
\hline & Economic & 14.3 & IT Budget & & \\
\hline & Engineering & 4.8 & & $<50 \%$ & 36.2 \\
\hline & Total & 100 & & $5-10 \%$ & 39.7 \\
\hline & & & & $11-15 \%$ & 12.1 \\
\hline & & & & $16-20 \%$ & 3.4 \\
\hline & & & & $>20 \%$ & 8.6 \\
\hline & & & & Total & 100 \\
\hline
\end{tabular}


The validity test was conducted by measuring convergent and discriminant validities. Table 2 shows that the AVE value for each construct is greater than 0.5 (0.652 to 0.783$)$, that it meets the criterion for convergent validity. In the meantime, according to [7], the discriminant validity was measured by comparing the square root of Average Variant Extracted (AVE) between latent variables and it has to be higher loading to its construct rather than loading to other constructs. Table 2 also shows that the square root of AVE for each variable was greater correlation to its construct rather than correlated with other constructs. In brief, the measurement model can be concluded that the latent variable has met the criterion of reliability and validity requirements.

Table 2. Inter-Construct Correlations (Diagonal bold values are square root of AVE); Composite Realiability (CR): Cronbach Alpha (CA)

\begin{tabular}{lccccccc}
\hline & Core R. & Adopt & Effort & Engag. R. & Perform & Societal R. & TechnR. \\
\hline Core R. & $\mathbf{0 . 8 1 8}$ & & & & & & \\
Adoption & 0.505 & $\mathbf{0 . 8 1 6}$ & & & & & \\
Effort & 0.416 & 0.445 & $\mathbf{0 . 8 6 7}$ & & & & \\
Engagement R. & 0.552 & 0.452 & 0.345 & $\mathbf{0 . 8 0 7}$ & & & \\
Performance & 0.492 & 0.435 & 0.540 & 0.359 & $\mathbf{0 . 8 7 1}$ & & \\
Societal R. & 0.468 & 0.433 & 0.514 & 0.436 & 0.390 & $\mathbf{0 . 8 4 7}$ & $\mathbf{0 . 8 8 5}$ \\
Technological R. & 0.325 & 0.436 & 0.308 & 0.380 & 0.378 & 0.448 & 0.783 \\
AVE & 0.669 & 0.666 & 0.752 & 0.652 & 0.759 & 0.717 & 0.97 \\
CR & 0.942 & 0.956 & 0.924 & 0.880 & 0.926 & 0.938 & 0.969 \\
CA & 0.929 & 0.950 & 0.890 & 0.813 & 0.895 & 0.921 & \\
\hline
\end{tabular}

\subsection{Structural Model Analysis}

The results of structural analysis (inner model) regarding hypotheses testing include readiness factor, adoption and performance which are shown in Figure1. There are six hypotheses tested between construct measured. The results show that 4 out of 6 hypotheses tested in total were supported and only 2 hypotheses were not significant. The societal and engagement readiness factors were not directly supported in adopting e-health system by Indonesian Hospitals, since the $\mathrm{P}$ value and $\mathrm{T}$ value did not meet to $5 \%$ significances $(0.484$ and 0.117$)$ as in Table 3 . In the meantime, variable of e-health adoption is identified as mediating variable to its impact on hospital performances (Table 3). Acceptance or rejection of the hypothesis is also done by comparing the value of $\mathrm{T}$ count with the $\mathrm{T}$ table and using the significance of the probability number. Therefore, $\mathrm{T}$ done is a two-way test (two tailed) with a significance level of 0.05 with $T$ table value of 1.993 . In the result of this research, it was calculated over $\mathrm{T}$ table, and then the independent variable partially has no effect towards the dependent variable. Statistical test results for all variables independent and dependent except societal and engagement readiness to e-health hypothesis are obtained the value of $\mathrm{T}$ counts more than $\mathrm{T}$ table that is above 1.93 and have achieve $\mathrm{p}$ value significance $\mathrm{p}<0.05$ or $\mathrm{p}<0.10$ (Table3).

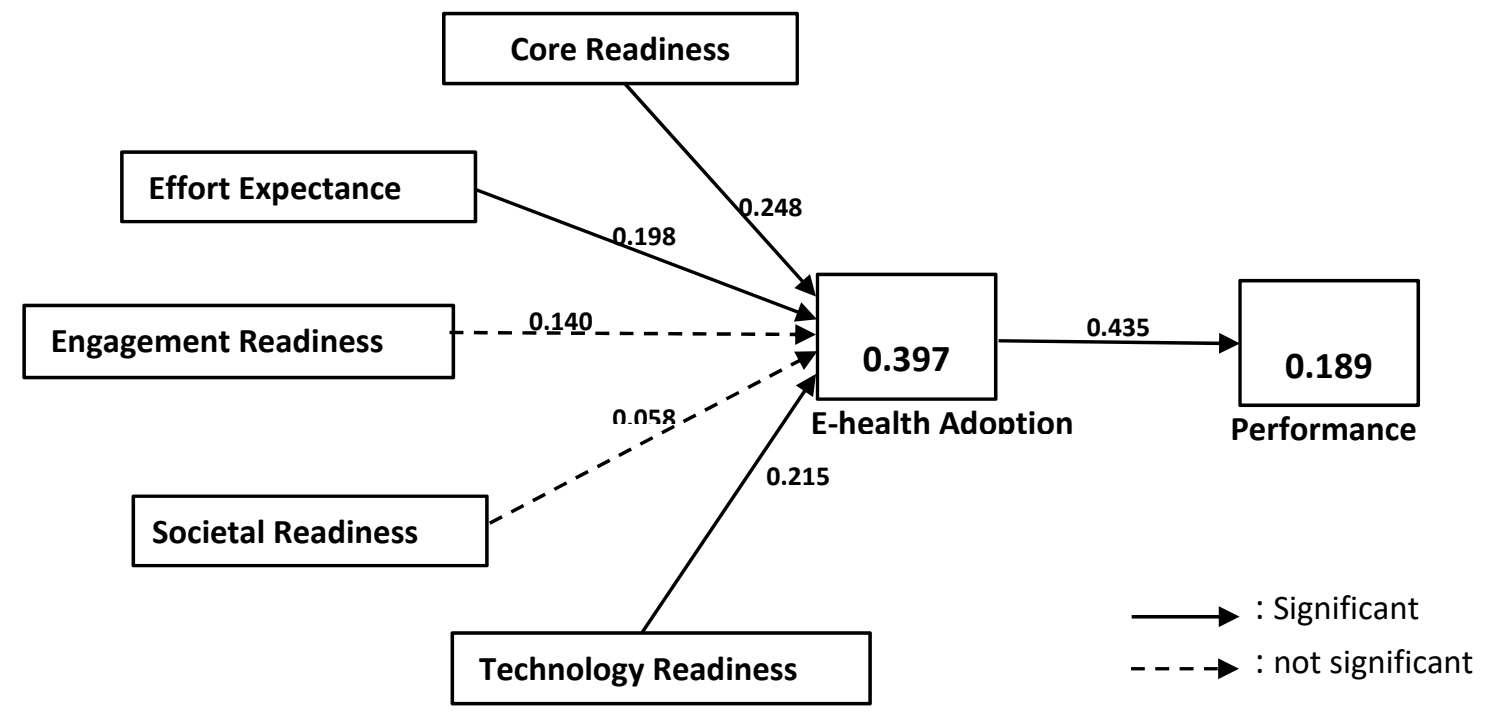

Figure 1. Structure model analysis 
Table 3. Structural Analysis by Direct Effects

\begin{tabular}{|c|c|c|c|c|c|}
\hline The Direct Effect & $\begin{array}{c}\text { Original } \\
\text { Sample (O) }\end{array}$ & $\begin{array}{c}\text { Sample } \\
\text { Mean (M) }\end{array}$ & STDE & T Statistics & $\begin{array}{l}\mathbf{P} \\
\text { Values }\end{array}$ \\
\hline H1: Core Readiness -> E-Health Adoption & 0.248 & 0.260 & 0.084 & 2.971 & $0.003 * *$ \\
\hline H2: Techn. Readiness -> E-Health Adoption & 0.215 & 0.217 & 0.064 & 3.359 & $0.001 * *$ \\
\hline $\begin{array}{l}\text { H3: Societal Readiness } \rightarrow \text { E-Health } \\
\text { Adoption }\end{array}$ & 0.058 & 0.054 & 0.083 & 0.701 & 0.484 \\
\hline H4: Engag. Readiness -> E-Health Adoption & 0.140 & 0.145 & 0.089 & 1.571 & 0.117 \\
\hline H5: Effort Expectance -> E-Health Adoption & 0.198 & 0.195 & 0.098 & 2.013 & $0.045 * *$ \\
\hline H6: E-Health Adoption -> Performance & 0.435 & 0.446 & 0.067 & 6.517 & $0.006^{* *}$ \\
\hline
\end{tabular}

$* *$ significance $\mathrm{p}<0.05$

\section{Discussion}

This study aims to investigate the adoption of ehealth systems among hospitals in Indonesia as a developing country whose concern to the readiness and performance may contribute. This research was the initial study toward adopting e-health through readiness model across Indonesia. The data was analyzed to test 6 hypotheses using Structural Equation Modelling with SmartPLS 3.00 towards variables e-health adoption and performance. Variables analyzed were readiness factors including core, technological, societal, engagement, effort and also performance as impact from mediating of ehealth adoption factors. The result of this study identified only 4 out of 6 hypotheses tested was not. The result of this study has shown that effects on ehealth adoption was influenced by the readiness of core, technology, effort conducted, and such hospitals have adopted e-health, and it predicted that they would be able to achieve organizational performance. By the investigation toward e-health adoption in Indonesian hospitals through readiness factors and their performance directly, the implementation of information systems in health industries has been believed as the main asset of numerous hospitals especially in delivering services to the public society.

The relationship between Readiness and Adoption; the readiness construct of this research included the core, technology, society, engagement and effort which were tested with reference to the relationship on e-health adoption. The result showed 4 out of 6 hypotheses were supported, that are the core; technology and effort have significantly directly impacted on e-health adoption. It is illustrations that adopt e-health in Indonesian hospitals; they may become a concern related to internal needs about information systems process and organizational purposes. It related to any preparations to be able to change organizationally, technologically and personally to get benefits of them. However, to adopt e-health in Indonesia, the readiness of society and engagement are identified not supported, consequently, further research may contribute to have successful implementation of e-health in Indonesia and find factors which have not been successfully applied yet. So, Indonesia information health system can be well used and support public health service better than developed countries have done.

Meanwhile, the relationships between adoption and performance; in terms of the adoption construct, it is significant influence on performance since using information systems in its hospitals as showed in detail data above in Figure 1 and Table 3. This is related to the progress and success of e-health implementation through the adoption of welldeveloped e-health in Indonesia as a developing country which follows the success of the health systems of developed countries such as Australia, the United States and European countries. Therefore, Indonesian hospitals may prepare some planning to adopt the integrated hospital information systems, imitate or adopted advanced e-health system from foreign countries.

This research was conducted on the readiness of information systems in various hospitals in Indonesia and the majority of hospital workers are relatively busy in providing services to the public and patients rather than to manage and entry data from a proportional activity to e-health and hospital information systems in Indonesian hospitals. However, from this study, data analysis has represented enough e-health reflection of Indonesia as the data obtained from a national participant came from representative of various hospitals in Indonesia. This study investigates the influence of readiness factors on adoptions and their impact on organizational performance in 104Indonesian Hospitals. Therefore, in adopting e-health in Indonesia, they should develop concern toward the factor of readiness which is predicted to have impact on the performance organizationally.

The study has the research limitations. First, such type of hospitals in Indonesia is diverse; it means that the research result is unclear. Second, research sample are hospital managerial people who are difficult to ask to collaborate with this research, consequently, only small sample is provided. 
For the further research specifically, the classification of respondent based on hospital class/ level should be more focused on analyzing the adoption model. The respondent has to have clear information and act as user of e-health to get more objective results. Another related investigation might not need to find any barrier or resistance of e-health implementation across in Indonesia areas since platform and facilities from government have already been built. Furthermore, such the topic of e-health adoption is very broad, thus specific information systems in healthcare and hospitals also need to be studied. The result of this study is going to give potential solution in adopting related information systems, especially e-health purposes to improve their performance especially in Indonesia contexts and as well as for other developing countries.

\section{Conclusion}

This study had been conducted to measure e-health adoption among Indonesian hospitals based on managerial staff perspectives that have experience in work with it. Based on the research result, in adopting e-health, the factor of core readiness, technological readiness and effort expectances significantly influenced, and they also have impact on personal performance during using e-health in their jobs. Accordingly, the hospital management is able to consider the readiness factor in adopting e-health related to core activities in hospital especially in support health service delivery and technologically properness used.

\section{Acknowledgement}

This research funded by the Indonesian Minister of Research and Technology, Higher Education in the grant of International collaborations and Scientific Publication 2018-2109.

\section{References}

[1]. Jung, M. L., \& Loria, K. (2010). Acceptance of Swedish e-health services. Journal of Multidisciplinary Healthcare, 3, 55-63.

[2]. Cho, Y. M., Lee, S., Islam, S. M. S., \& Kim, S. Y. (2018). Theories applied to $\mathrm{m}$-health interventions for behavior change in low-and middle-income countries: a systematic review. Telemedicine and $e$ Health, 24(10), 727-741.

[3]. Xu, J., Gao, X., Sorwar, G., \& Croll, P. (2013). Implementation of e-health record systems in Australia. The International Technology Management Review, 3(2), 92-104.

[4]. LeRouge, C., Mantzana, V., \& Wilson, E. V. (2007). Healthcare information systems research, revelations and visions. European Journal of Information Systems, 16(6), 669-671.
[5]. Mauco, K.L., Scott, R.E., \& Mars, M. (2020). Validation of e-health readiness assessment framework for developing countries. BMC Health Service Research, 20(50), 575.

[6]. Kalema, B. M., \& Kgasi, M. R. (2014). Leveraging EHealth for Future-Oriented Healthcare Systems in Developing Countries. The Electronic Journal of Information Systems in Developing Countries, 65(1), $1-11$.

[7]. Sekaran, U., \& Bougie, R. (2016). Research methods for business: A skill building approach. John Wiley \& Sons.

[8]. Qureshi, Q. A., Shah, B., Kundi, G. M., Nawaz, A., Miankhel, A. K., Chishti, K. A., \& Qureshi, N. A. (2013). Infrastructural barriers to e-health implementation in developing countries. European Journal of Sustainable Development, 2(1), 163-163.

[9]. Nengomasha CT., Abankwah R., Uutoni W. (2018). Health information systems in Namibia. Information and Learning Service, 119(7/8), 358-376.

[10]. Durrani, H., Khoja, S., Naseem, A., Scott, R. E., Gul, A., \& Jan, R. (2012). Health needs and eHealth readiness assessment of health care organizations in Kabul and Bamyan, Afghanistan. EMHJ-Eastern Mediterranean Health Journal, 18 (6), 663-670, 2012.

[11]. Haryanto, E. (2013). Kualitas layanan, fasilitas dan harga pengaruhnya terhadap kepuasan pengguna jasa layanan pada kantor samsat Manado. Jurnal EMBA: Jurnal Riset Ekonomi, Manajemen, Bisnis dan Akuntansi, 1(3).

[12]. Braa, J., Sahay, S., Lewis, J., \& Senyoni, W. (2017, May). Health information systems in indonesia: understanding and addressing complexity. In International Conference on Social Implications of Computers in Developing Countries (pp. 59-70). Springer, Cham.

[13]. Indonesian Ministry of Health (2019), "Profile Kesehatan Indonesia 2018", Jakarta: Kementrian Kesehatan Republik Indonesia, ISBN 978-602-656446-4,

[14]. Indartono, K. (2013). Sistem telemedika berbasis ICT untuk manajemen fasilitas unit gawat darurat. Jurnal teknik elektro, 5(1).

[15]. Internet World Stats. (2020). Internet users distributions. Retrieved from:

https://www.internetworldstats.com/stats.htm, [Accessed: 26 August 2020].

[16]. Igbaria, M., Iivari, J., \& Maragahh, H. (1995). Why do individuals use computer technology? A Finnish case study. Information \& management, 29(5), 227238.

[17]. Handayani, P. W., Meigasari, D. A., Pinem, A. A., Hidayanto, A. N., \& Ayuningtyas, D. (2018). Critical success factors for mobile health implementation in Indonesia. Heliyon, 4(11), e00981. https://doi.org/10.1016/j.heliyon.2018.e00981.

[18]. Khoja, S., Scott, R. E., Casebeer, A. L., Mohsin, M., Ishaq, A. F. M., \& Gilani, S. (2007). e-Health readiness assessment tools for healthcare institutions in developing countries. Telemedicine and $e$ Health, 13(4), 425-432. 
[19]. Jennett, P. A., Gagnon, M. P., \& Brandstadt, H. K. (2005). Preparing for success: readiness models for rural telehealth. Journal of postgraduate medicine, 51(4), 279.

[20]. Zhou, T., Lu, Y., \& Wang, B. (2010). Integrating TTF and UTAUT to explain mobile banking user adoption. Computers in human behavior, 26(4), 760767.

[21]. Davis, F. D. (1989). Perceived usefulness, perceived ease of use, and user acceptance of information technology. MIS Quarterly, 319-340.

[22]. Ketikidis, P., Dimitrovski, T., Lazuras, L., \& Bath, P. A. (2012). Acceptance of health information technology in health professionals: an application of the revised technology acceptance model. Health Informatics Journal, 18(2), 124-134.

[23]. Rogers, E. M. (2003). Diffusion of innovations, 5th edn Tampa. FL: Free Press.

[24]. Delone, W. H., \& McLean, E. R. (2003). The DeLone and McLean model of information systems success: a ten-year update. Journal of management information systems, 19(4), 9-30.

[25]. Venkatesh, V., Morris, M. G., Davis, G. B., \& Davis, F. D. (2003). User acceptance of information technology: Toward a unified view. MIS Quarterly, 425-478.

[26]. Kgasi, M., \& Kalema, B. (2014). Assessment Ehealth readiness for rural South African areas. J. Ind. Intell. Inf, 2(2).

[27]. Wickramasinghe, N. S., Fadlalla, A. M., Geisler, E., \& Schaffer, J. L. (2005). A framework for assessing ehealth preparedness. International Journal of Electronic Healthcare, 1(3), 316-334.
[28]. Molla, A., \& Licker, P. S. (2005). eCommerce adoption in developing countries: a model and instrument. Information \& management, 42(6), 877899.

[29]. Beebeejaun, M. R., \& Chittoo, H. (2017). An assessment of e-health readiness in the public health sector of Mauritius. Int J Sci Basic Appl Res, 35(1), 193-210.

[30]. Yusif, S., Hafeez-Baig, A., \& Soar, J. (2017). eHealth readiness assessment factors and measuring tools: A systematic review. International Journal of Medical Informatics, 107, 56-64.

[31]. Khoja, S., Durrani, H., Scott, R. E., Sajwani, A., \& Piryani, U. (2013). Conceptual framework for development of comprehensive e-health evaluation tool. Telemedicine and e-Health, 19(1), 48-53.

[32]. Rezai-Rad, M., Vaezi, R., \& Nattagh, F. (2012). Ehealth readiness assessment framework in Iran. Iranian Journal of Public Health, 41(10), 43.

[33]. Teo, T. S., \& Pian, Y. (2003). A contingency perspective on Internet adoption and competitive advantage. European Journal of Information Systems, 12(2), 78-92.

[34]. Molla, A., Peszynski, K., \& Pittayachawan, S. (2010). The use of e-business in agribusiness: investigating the influence of e-readiness and OTE factors. Journal of Global Information Technology Management, 13(1), 56-78.

[35]. Wynne, C. W. (1998). Issues and opinion on structural equation modelling. Management Information Systems Quarterly, 22(1), 1-8.

[36]. Hair Jr, J. F., Hult, G. T. M., Ringle, C., \& Sarstedt, M. (2016). A primer on partial least squares structural equation modeling (PLS-SEM). Sage Publications. 
TEM Journal. Volume 10, Issue 1, Pages 95-104, ISSN 2217-8309, DOI: 10.18421/TEM101-12, February 2021.

Appendix

\begin{tabular}{|c|c|c|c|c|c|}
\hline Constructs & Items & Loadings & $\begin{array}{l}\text { Composite } \\
\text { Reliability }\end{array}$ & $\begin{array}{l}\text { Cronbach's } \\
\text { Alpha }\end{array}$ & $\begin{array}{c}\text { Average } \\
\text { Variance } \\
\text { Extracted (AVE) }\end{array}$ \\
\hline $\begin{array}{l}\text { Core Readiness } \\
\text { (CR1) }\end{array}$ & Identification of needs & 0.786 & & & \\
\hline CR2 & Dissatisfaction with status quo & 0.699 & & & \\
\hline CR3 & Awareness about e-health & 0.847 & & & \\
\hline CR4 & Comfort with technology & 0.816 & & & \\
\hline CR5 & Trust on ICT & 0.874 & & & \\
\hline CR6 & Planning for new e-health project & 0.790 & 0.942 & 0.929 & 0.669 \\
\hline CR7 & Willingness to use & 0.867 & & & \\
\hline CR8 & Consideration of E-health & 0.852 & & & \\
\hline Technology & & & & & \\
\hline $\begin{array}{l}\text { Readiness } \\
\text { (TR1) }\end{array}$ & Speed and quality of internet & 0.789 & & & \\
\hline TR2 & Supporting of ICT services & 0.878 & & & \\
\hline TR3 & Hardware and software capability & 0.860 & & & \\
\hline TR4 & Reliability of the networks & 0.923 & & & \\
\hline TR5 & Institutional Internet training & 0.906 & & & \\
\hline TR6 & $\begin{array}{l}\text { Availability and Affordability of } \\
\text { ICT }\end{array}$ & 0.916 & 0.970 & 0.965 & 0.783 \\
\hline TR7 & $\begin{array}{l}\text { Hardware and software } \\
\text { Compatibility }\end{array}$ & 0.906 & & & \\
\hline TR8 & $\begin{array}{l}\text { Regulation and policy about using } \\
\text { e-health }\end{array}$ & 0.891 & & & \\
\hline TR9 & $\begin{array}{l}\text { Ethical and culture in } \\
\text { organization }\end{array}$ & 0.887 & & & \\
\hline $\begin{array}{l}\text { Societal } \\
\text { Readiness } \\
(\text { SoR1) }\end{array}$ & $\begin{array}{l}\text { Communication with other } \\
\text { organizations }\end{array}$ & 0.844 & & & \\
\hline SoR2 & $\begin{array}{l}\text { Sharing the content between } \\
\text { healthcare organization }\end{array}$ & 0.885 & & & \\
\hline SoR3 & $\begin{array}{l}\text { Social and culture factors among } \\
\text { staff }\end{array}$ & 0.803 & 0.938 & 0.921 & 0.717 \\
\hline
\end{tabular}




\section{Appendix (continued)}

\begin{tabular}{|c|c|c|c|c|c|}
\hline Constructs & Items & Loadings & $\begin{array}{l}\text { Composite } \\
\text { Reliability }\end{array}$ & $\begin{array}{c}\text { Cronbach' } \\
\text { s Alpha }\end{array}$ & $\begin{array}{l}\text { Average Variance } \\
\text { Extracted (AVE) }\end{array}$ \\
\hline SoR4 & $\begin{array}{l}\text { Community Position of economic } \\
\text { social }\end{array}$ & 0.862 & & & \\
\hline SoR5 & $\begin{array}{l}\text { Social and culture factors between } \\
\text { clients and community }\end{array}$ & 0.849 & & & \\
\hline SoR6 & $\begin{array}{l}\text { Providing care to patients and } \\
\text { community through collaboration } \\
\text { with health care institutions }\end{array}$ & 0.835 & & & \\
\hline \multicolumn{6}{|c|}{ Engagement } \\
\hline $\begin{array}{l}\text { Readiness } \\
\text { (EgR1) }\end{array}$ & Information on benefits & 0.893 & & & \\
\hline EgR2 & Financial on benefits & 0.833 & \multirow{5}{*}{0.880} & \multirow{5}{*}{0.813} & \multirow{5}{*}{0.652} \\
\hline EgR3 & Resistance to change & 0.602 & & & \\
\hline EgR4 & Continuing learning & $\mathrm{Na}$ & & & \\
\hline EgR5 & Learnability & 0.867 & & & \\
\hline Effort & & & & & \\
\hline $\begin{array}{l}\text { Expected } \\
\text { (EE1) }\end{array}$ & Experience using technology & 0.895 & \multirow{5}{*}{0.924} & \multirow{4}{*}{0.890} & \multirow{5}{*}{0.752} \\
\hline EE2 & Sophisticated of technology used & 0.879 & & & \\
\hline EE3 & Fluency using technology & 0.869 & & & \\
\hline EE4 & Vendor support & 0.822 & & & \\
\hline $\begin{array}{l}\text { E-health } \\
\text { Adoption } \\
\text { (EA1) }\end{array}$ & $\begin{array}{l}\text { Information on } \quad \text { growing } \\
\text { electronically in real time }\end{array}$ & 0.802 & & \multirow{11}{*}{0.950} & \\
\hline EA2 & $\begin{array}{l}\text { Stock availability (medicine, beds,) } \\
\text { and operator system availability }\end{array}$ & 0.825 & \multirow{10}{*}{0.956} & & \multirow{10}{*}{0.666} \\
\hline EA3 & Facilitations for Registration online & 0.870 & & & \\
\hline EA4 & $\begin{array}{l}\text { Electronically monitor of service } \\
\text { delivery }\end{array}$ & 0.870 & & & \\
\hline EA5 & $\begin{array}{l}\text { Electronically integrated and } \\
\text { connected to suppliers }\end{array}$ & 0.731 & & & \\
\hline EA6 & Provide online order with suppliers & 0.813 & & & \\
\hline EA7 & Provide online doctor's schedules & 0.847 & & & \\
\hline EA8 & $\begin{array}{l}\text { Provide online collaboration with } \\
\text { health agencies }\end{array}$ & 0.728 & & & \\
\hline EA9 & Provide feature for community online & 0.795 & & & \\
\hline EA10 & Provide access inter division & 0.802 & & & \\
\hline EA11 & Provide information relevant & 0.874 & & & \\
\hline $\begin{array}{l}\text { Performance } \\
\text { (P1) }\end{array}$ & Service quality & 0.809 & \multirow{4}{*}{0.926} & \multirow{4}{*}{0.895} & \multirow{4}{*}{0.759} \\
\hline $\mathrm{P} 2$ & Users satisfaction & 0.894 & & & \\
\hline P3 & Hospitals concern using e-health & 0.877 & & & \\
\hline P4 & Benefit excepted & 0.901 & & & \\
\hline
\end{tabular}

$\mathrm{Na}$; Not valid/ removed item 